\title{
A CHANGING TEMPERATURE RESPONSE WITH ELEVATION FOR LAGAROSTROBOS FRANKLINII IN TASMANIA, AUSTRALIA
}

\author{
B. M. BUCKLEY \\ IASOS, University of Tasmania, GPO Box 252-77, Hobart, TAS, Australia 7001 \\ E. R. COOK \\ Tree-Ring Laboratory, Lamont-Doherty Earth Observatory of Columbia University, Palisades, N.Y., \\ U.S.A. 10964 \\ M. J. PETERSON \\ Department of Plant Sciences, University of Tasmania, GPO Box 252-55, Hobart, TAS, \\ Australia 7001 \\ M. BARBETTI \\ NWG Macintosh Centre for Quaternary Dating, University of Sydney, Madsen Bldg. F09, Sydney, \\ NSW, Australia 2006
}

\begin{abstract}
A network of seven Huon pine ring-width chronologies is constructed from sites ranging in elevation from 200 to 950 metres above sea level in western Tasmania. The chronologies are analysed individually and collectively to explore Huon pine's response to climate as a function of elevation. Three chronologies from greater than 700 metres in elevation exhibit a strong, direct response to temperature for most growing season months $(p<0.05)$, while three from below 700 metres exhibit a weaker, direct response to growing-season temperature, and a strong, inverse relationship with temperature of the prior season of growth, also significant at the 0.05 level. Moisture availability at these temperate rainforest sites is less growth-limiting than temperature, and significant correlations for January (inverse) and April (direct) of the year of growth largely reflect the inter-relationships between temperature, precipitation and cloudiness, and their combined influence on photosynthesis, particularly at higher-elevation sites.

A rotated Principal Component Analysis reveals a clear grouping of the high and low-elevation chronologies, represented by the first and second eigenvectors, respectively. The 700 metre Lake Marilyn Low chronology is revealed to be a transitional site between the two groupings, and likely reflects an important climatic ecotone where both temperature and photosynthetically-active radiation drop below optimum levels for the species, and begin to directly inhibit growth.

Tasmania's west coast climate has been shown to exhibit a distinct vertical structure, exemplified by a subsidence-inversion layer above 900 metres. Temperature increases slightly with altitude above 930 metres (the elevation at which a peak in daily minimum and maximum humidity levels is observed) before decreasing again. A dense, orographically-generated cloud-zone of reduced light and temperature has a mean altitude between 700 and 900 metres, with the steepest drop in both air and soil temperature exhibited between 850 and 930 metres. This structure can account for Huon pine's changing response to climate with elevation as described in this paper, and reinforces the importance of careful site selection for dendroclimatic research. In the case of reconstructing warm-season temperature from Tasmanian Huon pine, the desired signal might be maximised through sampling at the few rare, subalpine stands which have been located in western Tasmania. The great length afforded by the low-elevation Huon pine resource may ultimately yield a far more detailed reconstruction of regional climate throughout the Holocene, with respect to a vertical profile, following the development of more sound, mechanistically-based response models.
\end{abstract}

Climatic Change 36: 477-498, 1997.

(C) 1997 Kluwer Academic Publishers. Printed in the Netherlands. 


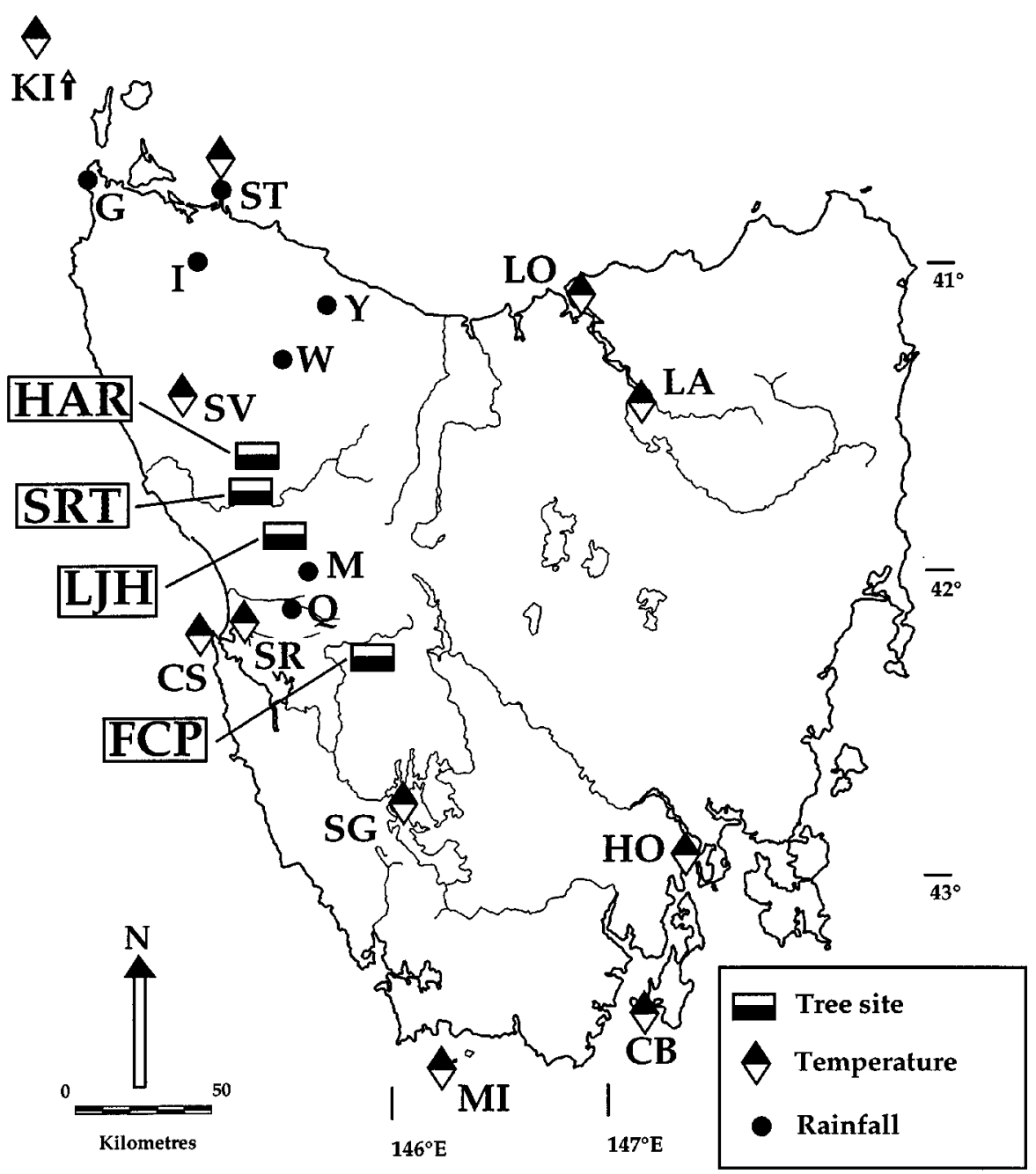

Figure 1. Huon pine sampling locations and the meteorological stations used for climatic calibration of the ring-width chronologies. The four sampling locations are: HAR = Harman River, SRT = Stanley River, $\mathrm{LJH}=$ Lake Johnston on Mt. Read, and FC = Frenchmans Cap where four sites were sampled as shown in Figure 4. The meteorological stations are: KI = King Island, ST = Stanley, LO = Low Head Lighthouse, $\mathrm{LA}=$ Launceston, $\mathrm{HO}=$ Hobart $\mathrm{CB}=$ Cape Bruny Lighthouse, $\mathrm{MI}=$ Maatsuyker Island Lighthouse, $\mathrm{SG}=$ Strathgordon, SR = Strahan, CS = Cape Sorrel Lighthouse, SV = Savage River, $\mathrm{G}=$ Cape Grim, $\mathrm{I}=$ Irishtown, $\mathrm{Y}=$ Yolla, $\mathrm{W}=$ Waratah, $\mathrm{M}=$ Lake Margaret, and $\mathrm{Q}=$ Queenstown.

\section{Introduction}

The Tasmanian endemic conifer Huon pine (Lagarostrobos franklinii, C. J. Quinn) has been used to reconstruct Austral warm-season (i.e., November-April) temperature for Tasmania, Australia over the past 3 millennia (Cook et al., 1992, 1995, 1996a,b). The ring-width chronology used for the reconstruction comes from Mt. 
Read in western Tasmania, and is one of seven Huon pine chronologies included in this study, the locations of which are shown in Figures 1-4. Buckley et al. (1993) suggest that the temperature response of Huon pine is elevation dependent, based on a limited sample of three sites: the subalpine LJH site from 950 metres above mean sea level (AMSL) on Mt. Read, and two low-elevation (i.e., < 500 metres), riparian sites from the Stanley River (SRT) and the Harman River (HAR), respectively. Samples from the latter two sites exhibit lobate growth, difficult crossdating and little agreement with trees from LJH. Response function analysis reveals a weaker, more complex temperature response for both SRT and HAR, compared with the strong, direct response of LJH to growing season temperature (Buckley et al., 1993; Cook et al., 1996a). Four new Huon pine chronologies have since been developed from the Frenchmans Cap region (Buckley, 1997), including three from elevations greater than 700 metres, allowing for a reassessment of Huon pine's climate response with respect to an elevational gradient in western Tasmania.

\section{Site Descriptions}

Mt. Read, at an elevation of 1,124 metres, is part of the first major orographic barrier on Tasmania's west coast, and is consequently in one of the wettest areas of the island with precipitation totals of ca. 3,000 mm annually (Bureau of Meteorology, 1993). Huon pine grow in two disjunct stands on the southern side of the mountain between 950 and 1,000 metres (Figure 2). The Lake Johnston site consists of two discrete, adjacent units around 950 metres AMSL, with the lower unit (LJH) consisting of approximately 300 living trees, while the uppermost portion (JDA) is made up entirely of trees killed by fire in 1961. A separate, disjunct stand (KDH) is located about 1.5 kilometres to the northwest, and at an elevation of 1,000 metres it is the highest-known occurrence of Huon pine in existence (Peterson, 1990). However, an 1898 fire killed nearly the entire stand, leaving only a small cluster of vegetatively-sprouted stems. The Mt. Read chronology (referred to collectively as $\mathrm{LJH}$ ) is built from core samples from living stems from the LJH live stand, combined with overlapping segments of subfossil logs excavated from all three locations; 88 from JDA and LJH combined, and 115 from KDH (Buckley, 1997). Not all of these subfossil logs have been included in the final chronology, however, due to circuit-uniformity problems or other growth anomalies in some samples where only root wood or branch material was recovered.

The SRT and HAR sites are located within the Pieman River Catchment, at 225 and 450 metres AMSL, respectively (Figure 3). SRT has been the focus of an interdisciplinary research project for more than a decade (e.g., Francey et al., 1984; Barbetti et al., 1992; 1995; Nanson et al., 1995). A modern chronology from living and subfossil trees, combined with two floating chronologies from subfossil logs, create a nearly-continuous coverage of the past 7,000 years. Average annual rainfall at nearby Queenstown and Strahan is around 2,000 $\mathrm{mm}$, while mean daily maximum 


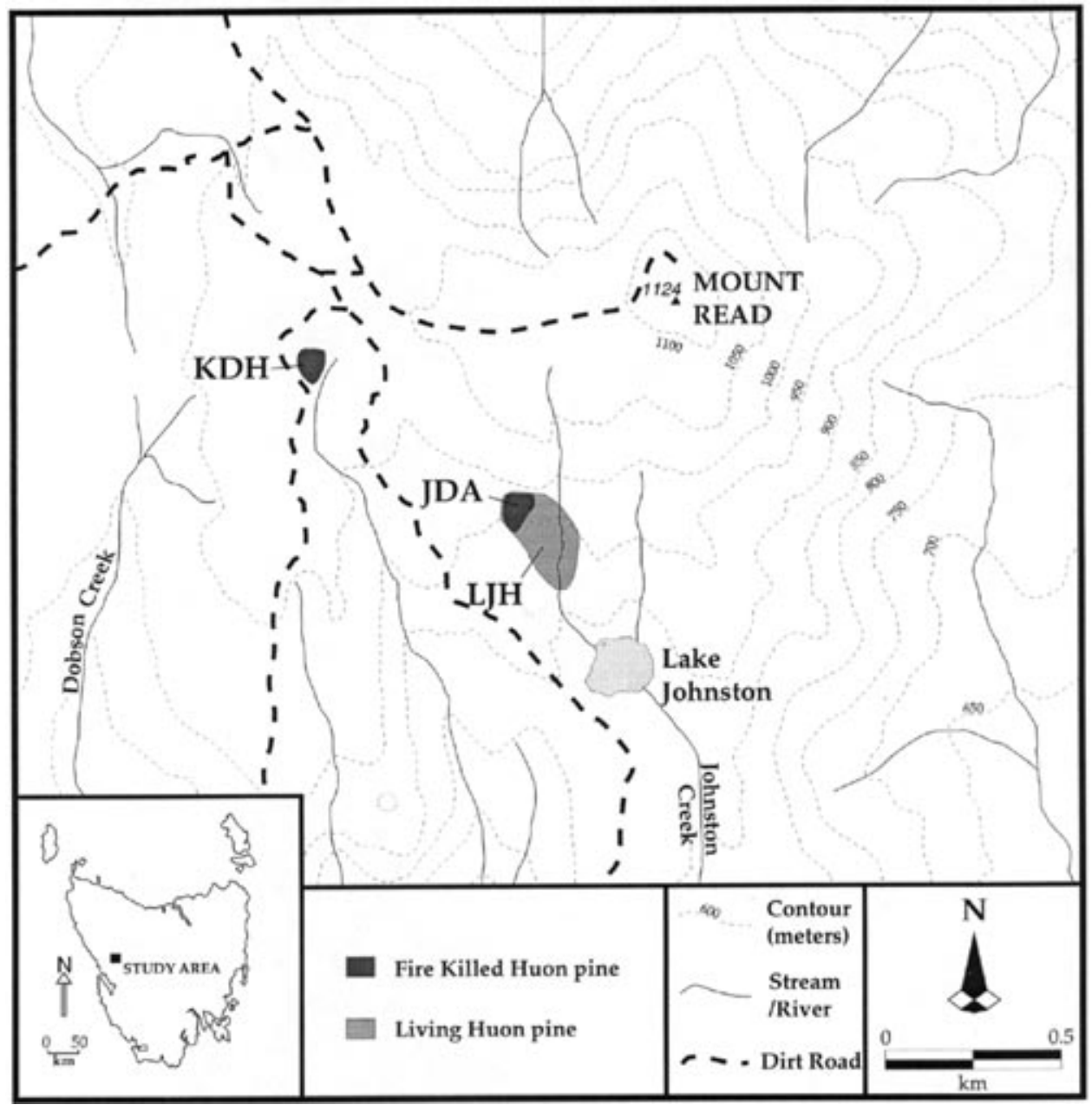

Figure 2. Mt. Read site map showing Huon pine sampling locations. The Mt. Read chronology, referred to collectively as $\mathrm{LJH}$, is built from core samples from living trees from $\mathrm{LJH}$, subfossil logs and standing dead stems from JDA, and subfossil logs excavated from $\mathrm{KDH}$.

temperature ranges from around $20^{\circ} \mathrm{C}$ in January to $9^{\circ} \mathrm{C}$ in July, and minima range from around $9^{\circ}$ to $3^{\circ}$ in January and July, respectively. HAR was visited in 1991 and 1992, and sampling was limited to the coring of 32 living trees and 3 non-living, downed logs from a protected riparian zone on granite substrate, with shallow sandy soil. Like SRT, the HAR stand exists as an isolated, relict rainforest patch surrounded by sclerophyll forest and Gymnoschoenus sphaerocphalus-dominated sedgeland where fires have burned much of the surrounding area. Trees at both sites are largely river-bank specimens, subject to mechanical disturbance from channel undercutting and flood-carried debris. Therefore, annual rings are often distorted due to reaction wood or compression wood, and ring 'wedging', resulting in gen- 


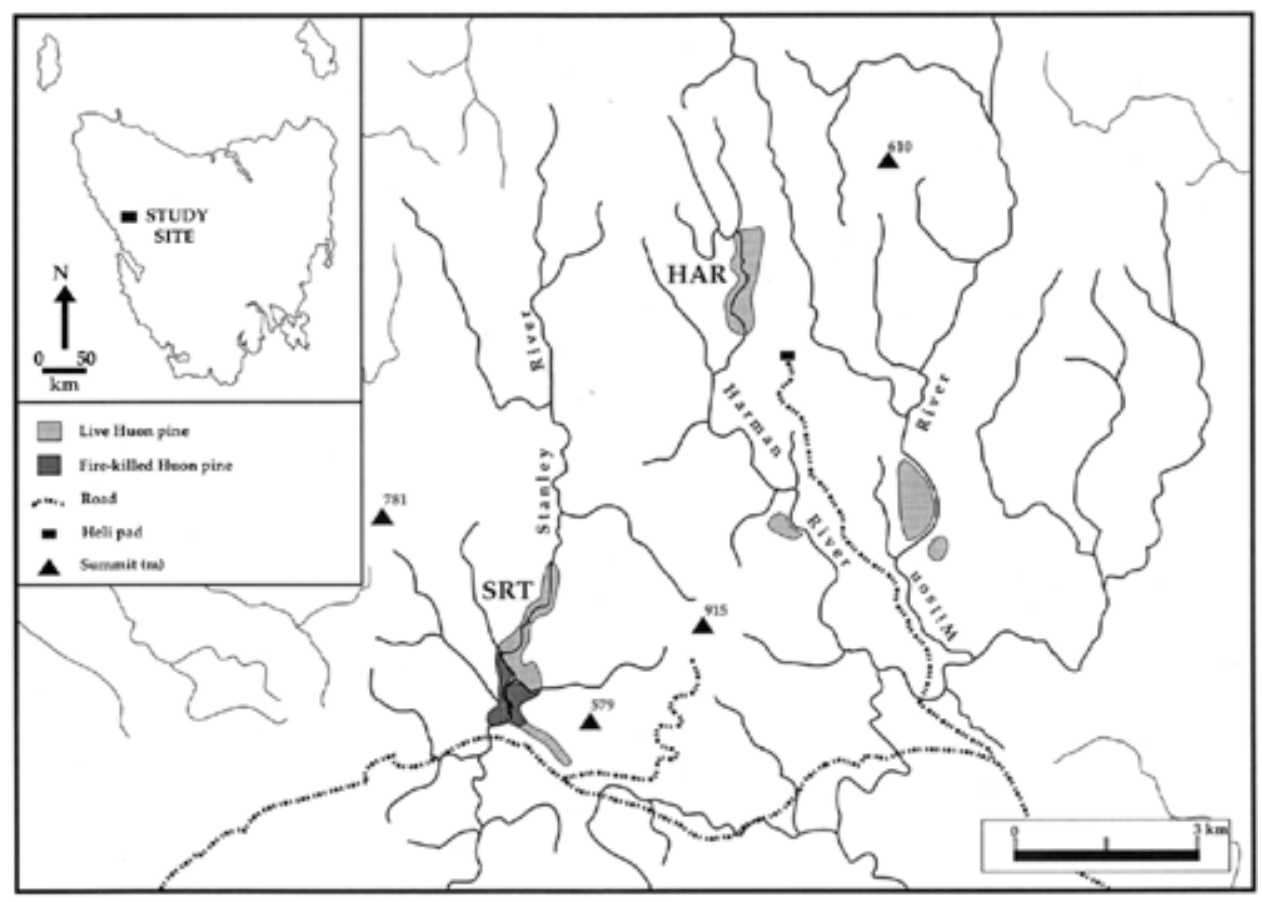

Figure 3. Site map for the two Pieman River Catchment chronologies; the Stanley River (SRT) and the Harman River (HAR).

Table I

Details from the seven Huon pine chronologies. The column labelled 'Corr' lists the series intercorrelation for each chronology, a measure of the year-to-year agreement between all ring-width series, while 'AR $(p)$ ' is the mean autocorrelation coefficient for each chronology

\begin{tabular}{llrllll}
\hline No. & Site name & Time span & No. of years & Elevation & Corr. & $\operatorname{AR}(p)$ \\
\hline 1 & LJH & $-1741-1990$ & 3732 & ca. $950 \mathrm{~m}$ & 0.506 & 0.822 \\
2 & BCH & $910-1991$ & 1082 & ca. $900 \mathrm{~m}$ & 0.530 & 0.836 \\
3 & LMH & $1542-1992$ & 451 & ca. $800 \mathrm{~m}$ & 0.453 & 0.831 \\
4 & LML & $1058-1992$ & 935 & ca. $700 \mathrm{~m}$ & 0.523 & 0.787 \\
5 & LVH & $69-1993$ & 1925 & ca. $550 \mathrm{~m}$ & 0.501 & 0.882 \\
6 & HAR & $-2-1990$ & 1993 & ca. $500 \mathrm{~m}$ & 0.384 & 0.799 \\
7 & SRT & $-571-1982$ & 2554 & ca. $200 \mathrm{~m}$ & 0.457 & 0.809 \\
\hline
\end{tabular}

erally poor crossdating as indicated by the low series intercorrelations statistics shown in Table I.

The known locations and extent of Huon pine stands in the Frenchmans Cap region are presented in Figure 4, with the four sampling locations highlighted. The BCH stand, situated between 800 and 900 metres AMSL, is one of 


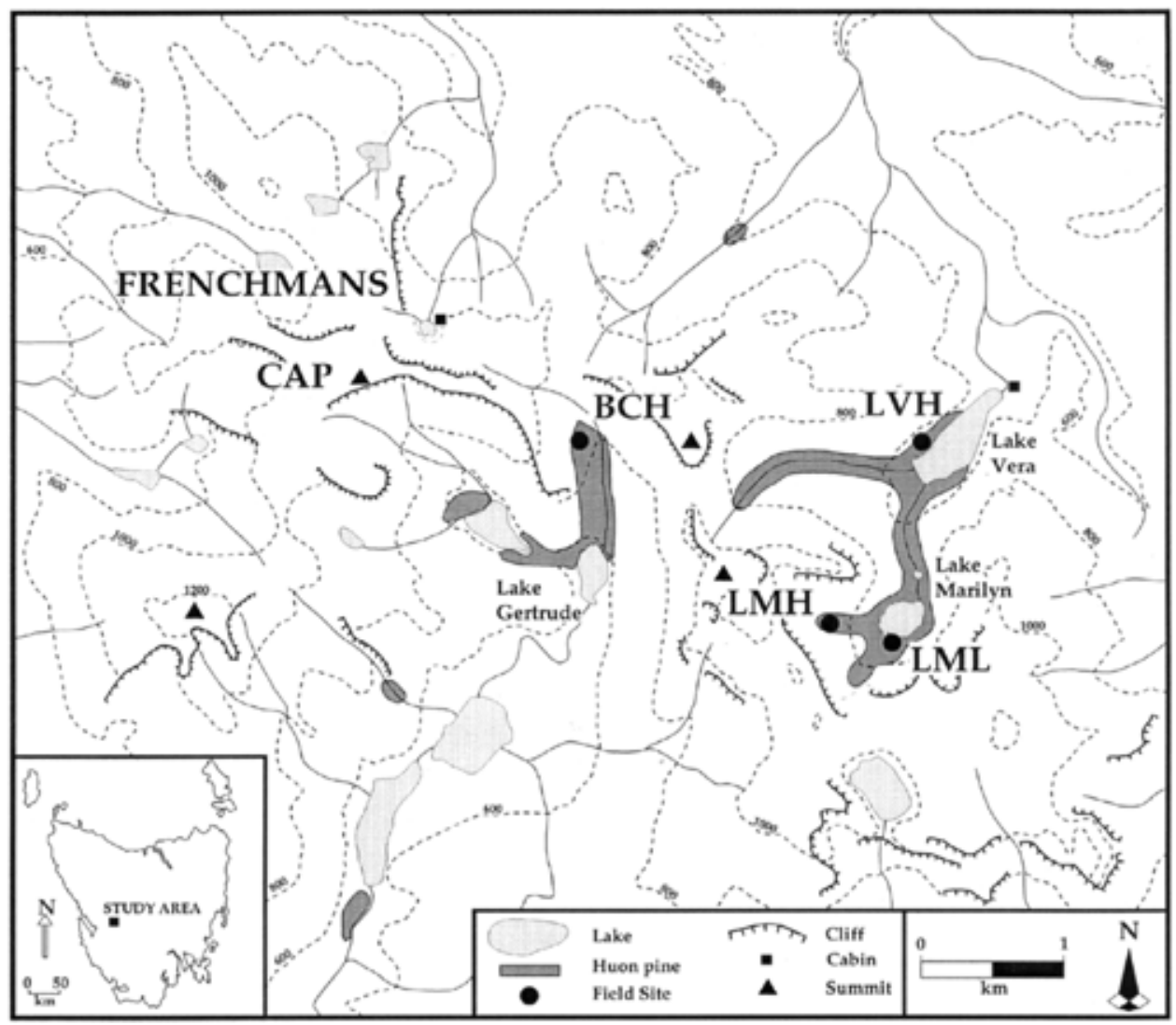

Figure 4. Huon pine sampling locations in the Frenchmans Cap region. BCH = Buckley's Chance Huon; LMH = Lake Marilyn High; LML = Lake Marilyn Low; LVH = Lake Vera Huon.

the highest-known occurrences of the species, and was first reported by Hickey and Felton (1988). The plant community in the interior of BCH is implicate rainforest, after the nomenclature of Jarman et al. (1984), and co-dominant with Lagarostrobos franklinii are old-growth Athrotaxis selaginoides, with both species attaining heights up to 10 metres. Other canopy species include Eucryphia lucida, Nothofagus cunninghamii and Phyllocladus aspleniifolius, with dense tangles of Anodopetalum biglandulosum found throughout the interior of the stand.

Huon pine in the Lake Marilyn catchment are divided into two sampling populations known as LMH and LML, at around 800 and 700 metres AMSL, respectively. These two collections consist of core samples from living trees only; 14 from LMH, and 15 from LML, with no subfossil logs sampled from either stand. The upper boundary of LMH forms a ragged ecotone with wet-sclerophyll forest dominated by widely-scattered Eucalyptus spp., marking the limits of recent burning. LML consists of mature Huon pine growing in dense rainforest along the southern and western shores of Lake Marilyn. The oldest tree from this site germinated before 
AD 620, with several others extending before AD 1300. A dense understory, dominated by Anodopetalum biglandulosum, is overtopped by occasional old-growth Nothofagus cunninghamii, Phyllocladus aspleniifolius and Atherosperma moschatum. Many downed and half-buried logs are found on the forest floor, while several more are detected by probing the deep sediments of the near-shore margins of the lake.

The final sampling location is at Lake Vera (LVH) where both living trees and subfossil logs were sampled. Vegetation around the lake is highly dependant upon aspect, with Huon pine-dominated, implicate rainforest found along the northwestern shore where fire has been largely excluded. The west-facing slopes are fire-prone, with young, even-aged stands of Eucalyptus nitida growing in open forest from the lakeshore to the timberline at ca. 860 metres (Macphail, 1979). Forty three subfossil Huon pine logs were recovered from the lake bottom along the western shore in the summer of 1994 (Buckley, 1997). These were combined with core samples from 29 living stems from the western shore immediately adjacent to the lake sampling location. The oldest living tree germinated before AD 610, with several more dating back before AD 1000. Subfossil logs extend the chronology back to AD 67, with several logs remaining undated, and likely pre-date the chronology (Buckley, 1997).

\section{The Chronologies}

The seven ring-width chronologies are plotted in Figure 5, shown back only to AD 1500 to emphasise the common period, with relevant chronology information listed in Table I. Standard techniques are used in developing the ring-width time series, from sample preparation to crossdating (e.g., Stokes and Smiley, 1968; Fritts, 1976; Hughes et al., 1982; Cook and Kairiukstis, 1990). Standardisation for all chronologies follows the procedures outlined in Cook et al. (1992), where the variance of individual series is stabilised using a data-adaptive power transformation prior to detrending by taking the residuals from a cubic smoothing spline with a 50\% frequency-response cutoff of 500 years. This procedure effectively eliminates the possibility of introducing bias into the final series, which can occur as a result of the division process used for the traditional ratios methods of standardisation (see Cook et al., 1992). Autoregressive modelling is applied to each series (Cook, 1985; 1987), and the bi-weight robust mean is used to reduce the influence of outliers in the computation of the mean chronologies. A correlation matrix for all seven of the prewhitened Residual chronologies is shown in Table II, which demonstrates the degree of regional crossdating between sites, with emphasis on high-frequency variability. A clustering into two groups based on elevation is suggested, with the strongest correlations exhibited between the three highest chronologies. 


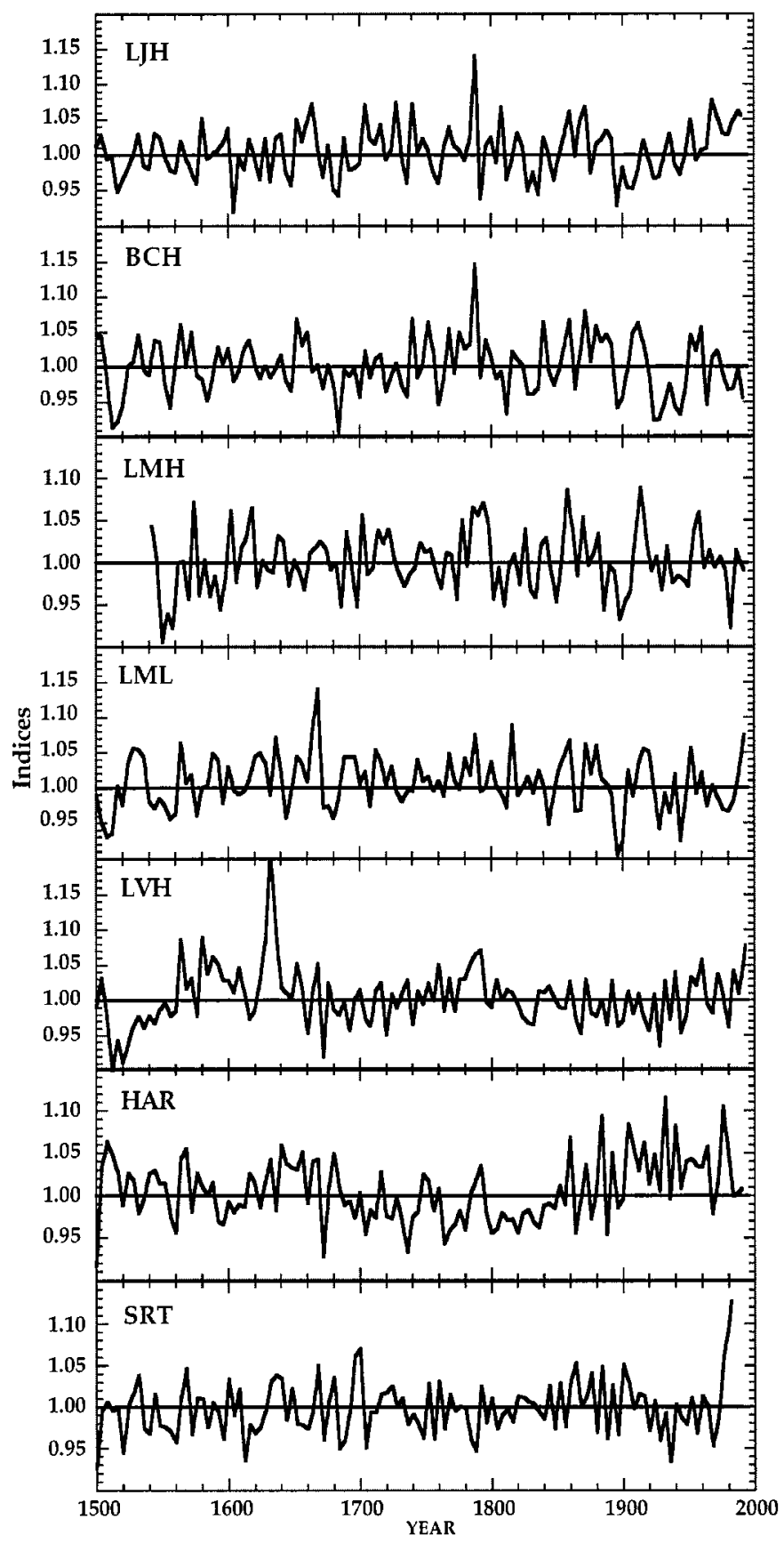

Figure 5. Chronology Plots from AD 1500. Each series has been smoothed with a 10-year low-pass filter for visual clarity. 
Table II

Correlation matrix for the seven pre-whitened Residual chronologies

\begin{tabular}{llllllll}
\hline & LJH & BCH & LMH & LML & LVH & HAR & SRT \\
\hline LJH & $\mathbf{1 . 0 0 0}$ & 0.729 & 0.631 & 0.611 & 0.543 & 0.466 & 0.439 \\
BCH & 0.729 & $\mathbf{1 . 0 0 0}$ & 0.771 & 0.596 & 0.473 & 0.260 & 0.360 \\
LMH & 0.631 & 0.771 & $\mathbf{1 . 0 0 0}$ & 0.638 & 0.612 & 0.308 & 0.338 \\
LML & 0.611 & 0.596 & 0.638 & $\mathbf{1 . 0 0 0}$ & 0.640 & 0.466 & 0.431 \\
LVH & 0.543 & 0.473 & 0.612 & 0.640 & $\mathbf{1 . 0 0 0}$ & 0.540 & 0.462 \\
HAR & 0.466 & 0.260 & 0.308 & 0.466 & 0.540 & $\mathbf{1 . 0 0 0}$ & 0.514 \\
SRT & 0.439 & 0.360 & 0.338 & 0.431 & 0.462 & 0.514 & $\mathbf{1 . 0 0 0}$ \\
\hline
\end{tabular}

\section{Meteorological Data}

The temperature time-series used for calibration of the LJH chronology by Cook et al. $(1991,1992,1996 \mathrm{a})$ is a composite of three meteorological station records, all from below 100 metres in elevation on the eastern side of the island (Figure 1 and Table III). The use of this 'Cook Series' for calibration is justified because of its great length (1885-1989) compared with the short, discontinuous records from the west coast (Cook et al., 1992). These stations are also considered to be three of the highest-quality, long records from Tasmania, following several corrections to account for problems related to station moves and equipment changes (Torok, 1996; pers. comm.). While the tree sites are from Tasmania's west coast mountain ranges and in a different meteorological district (Bureau of Meteorology, 1993), the variations in temperature across the island are fairly uniform and mostly governed by elevational changes and distance from the coast (Langford, 1965; Gentilli, 1972). Cook et al. (1992) demonstrate that the composite accurately represents the temperature variations in several high-elevation stations of the west coast, with correlations of 0.90 or greater for ten of the twelve months, including all of the warm season months. That assessment is confirmed by Buckley (1997), who compares daily and monthly data from around the state with the individual records comprising the Cook Series. Even daily temperature data from 950 metres on Mt. Read show high correlations with daily records from lower-elevation stations throughout the state (see Table IV).

Additional evaluations of the Cook Series are carried out by Cook et al. (1996b) who compare it against a temperature time-series developed by P. D. Jones (University of East Anglia, U.K.), referred to henceforth as the 'Jones Series', and by Buckley (1997) who develops a more geographically-representative series from 9 coastal stations completely surrounding Tasmania, referred to as the 'Buckley Series' (see Figure 1 and Table III). The Jones Series, originally expressed in anomaly units, is based on Hobart air temperature, as well as sea surface temperature (SST) data from within a $5^{\circ} \times 5^{\circ}$ grid square that completely encompasses Tasmania. The original anomaly units are transformed into absolute temperatures 
Table III

The nine temperature records comprising the Buckley Series. The station elevations and their timespans are shown, along with the mean warm-season (November to April) values for minimum, maximim, and mean temperatures $\left({ }^{\circ} \mathrm{C}\right)$ for the common period of 1937 to 1970 . The stations in bold-face were also used for development of the Cook Series

\begin{tabular}{lrllrll}
\hline Station & Elev. (m) & First yr. & Last yr. & Min & Max & Mean \\
\hline King Island & 24 & 1919 & 1993 & 11.45 & 18.77 & 15.11 \\
Stanley & 10 & 1896 & 1975 & 11.13 & 18.60 & 14.86 \\
Low Head LH & 28 & 1896 & 1993 & 11.61 & 18.51 & 15.06 \\
Launceston & 166 & 1886 & 1993 & 8.69 & 20.63 & 14.66 \\
Hobart & 5 & 1883 & 1993 & 10.18 & 19.68 & 14.93 \\
Cape Bruny LH & 5 & 1925 & 1995 & 10.16 & 16.72 & 13.44 \\
Maatsuyker Is. LH & 147 & 1937 & 1995 & 9.67 & 15.78 & 12.73 \\
Strahan & 7 & 1901 & 1991 & 11.05 & 16.96 & 14.00 \\
Cape Sorrel & 19 & 1901 & 1970 & 11.05 & 16.96 & 14.00 \\
\hline
\end{tabular}

Table IV

Mt. Read daily temperature correlations with six other stations, the locations of which are shown in Figure 1. Listed are the values for $r$ based on simple linear regression for the minimum, maximum, and mean daily values from each station with the same parameter from the AWS on Mt. Read for a 182 day period

\begin{tabular}{llll}
\hline & Mt. Read min. & Mt. Read max. & Mt. Read mean \\
\hline Hobart & 0.795 & 0.704 & 0.824 \\
Launceston & 0.797 & 0.803 & 0.872 \\
Low Head & 0.803 & 0.709 & 0.830 \\
Queenstown & 0.693 & 0.731 & 0.864 \\
Strathgordon & 0.883 & 0.705 & 0.866 \\
Strahan & 0.679 & 0.759 & 0.812 \\
\hline
\end{tabular}

by regressing them on the Cook Series (Cook et al., 1996b). While the two timeseries are not completely independent of each other (i.e., both include the Hobart record) the methods used for regionalisation of the data are different, and the Jones Series are corrected for inhomogeneity problems in the SST data. In spite of these differences, the Cook and Jones Series are very similar $(r=0.863)$ for the entire common period of 1885-1994, as shown in Figure 6. The Buckley and Cook warm-season records are nearly identical $(r=0.976)$, in spite of the addition of 6 widely-spaced station records to the former, and the Buckley and Jones series are also quite similar $(r=0.859)$.

For the Buckley Series, monthly mean minimum, maximum, and mean temperature data from nine stations are standardised to a common mean and standard deviation, following several corrections made to individual station records based on 

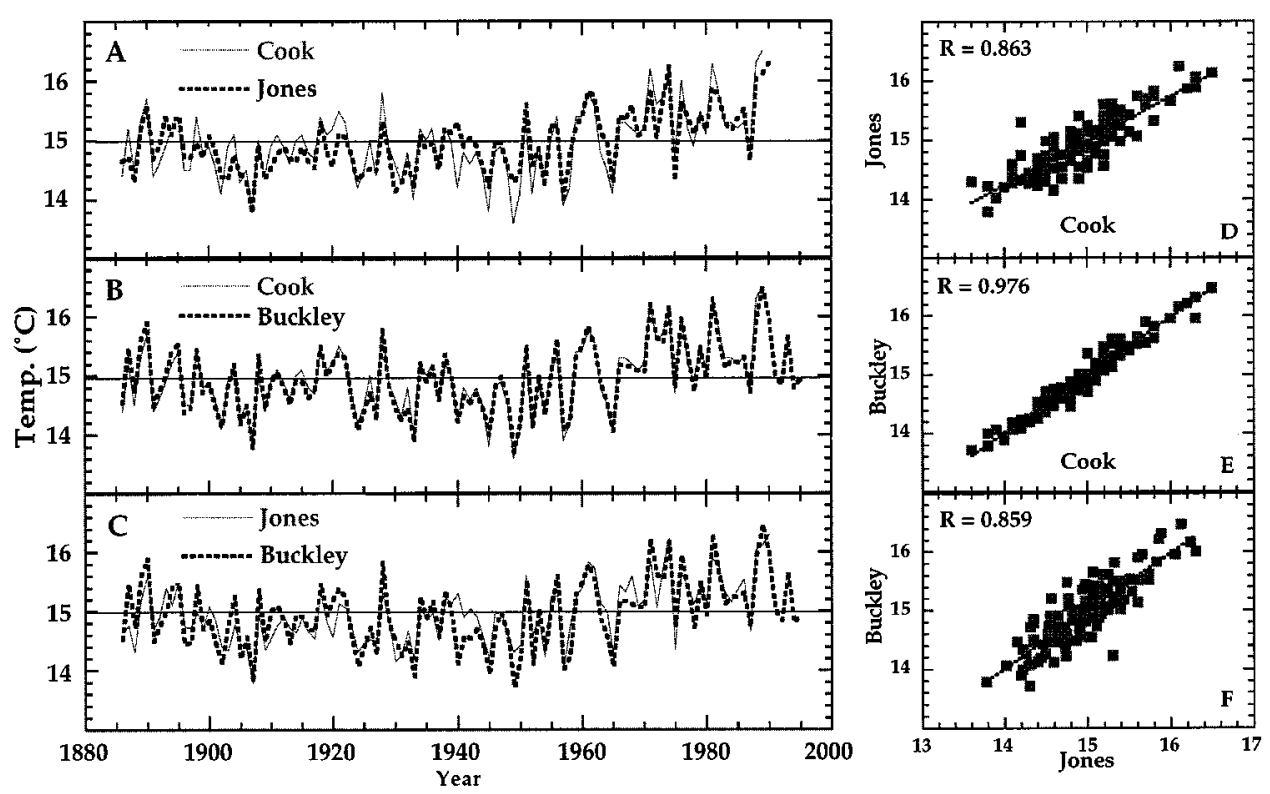

Figure 6. Comparison of three warm-season temperature series from Tasmania.

the findings of Torok (1996; pers. comm.). A warm-season (Nov.-Apr.) time series is developed, which reveals a latitudinal temperature gradient of about $2.38^{\circ} \mathrm{C}$ (1.78 for min., $2.99^{\circ}$ for max.) for the common period (1937-1970), based on the difference between King Island in Bass Strait and Maatsuyker Island off the southern coast of Tasmania. The sea-level temperature equivalent for the latitude of Mt. Read is based on Strahan and Cape Sorrel, which have a mean for the common period of $14{ }^{\circ} \mathrm{C}$.

The precipitation record used for calibration is a composite of seven westcoast stations, shown in Figure 1 and listed in Table V, which are expressed as the average normal standard deviates of the original data from 1915-1990 (data supplied by K. Allen, University of Tasmania). Additional comparisons were made with individual station records (e.g., Queenstown, King Island, Maatsuyker Island) with nearly identical results, and are therefore not included.

\section{Climate Response of Huon Pine}

The correlation-function plots for the seven chronologies with temperature and precipitation are shown in Figure 7. A dendroclimatic window of 21 months is used, from May of the season of growth (year $t$ ) back 21 months to September of year $t-1$. Prior to regression, both the tree-ring and temperature data are prewhitened through autoregressive modelling, accounting for the loss of one year of temperature data. The creation of the 21-month dendroclimatic window accounts 
Table V

The seven rainfall stations used for the west coast precipitation record. The final time series is expressed as the average normal standard deviates of the original data from 19151990. (data supplied by K. Allen, University of Tasmania)

\begin{tabular}{llll}
\hline Station & Elevation $(\mathrm{m})$ & First year & Last year \\
\hline Yolla & ca. 300 & 1905 & 1990 \\
Cape Grim & ca. 90 & 1888 & 1990 \\
Stanley & ca. 10 & 1868 & 1990 \\
Lake Margaret & ca. 600 & 1912 & 1990 \\
Queenstown & ca. 130 & 1906 & 1990 \\
Waratah & ca. 550 & 1882 & 1973 \\
Irishtown & ca. 100 & 1906 & 1990 \\
\hline
\end{tabular}

for the loss of an additional 2 years, reducing the final data set to 1888-1989. Prewhitening the precipitation series has virtually no effect on the results, and is not employed here. Thus, the timespan of the precipitation data is from 1916-1989.

The correlation functions are similar for all chronologies, however the three sites from elevations higher than 700 metres (HIGH) exhibit a far stronger response to warm season climate in year $t$, while the lower sites (LOW) respond more vigorously to the growth season of the previous year. Cook et al. (1992) identify the season of strongest temperature response as November to April, however only LJH shows significance for November (with minimum and mean temperature), while $\mathrm{BCH}$ is the only site to show significance for December (maximum temperature only). The strongest response 'window' for all of the HIGH sites is clearly from January through April, with much of the correlation in January related to the influence of maximum temperature, and much of April's correlation related to minimum temperature. This is augmented by a significant response with precipitation for these same months; i.e., an inverse correlation with January, and a direct response to April rainfall for all of the HIGH chronologies. Low precipitation in January corresponds to higher maximum temperatures and increased photosynthetically-active radiation (PAR) during the early growing season, while high April rainfall results in lower maximum, yet higher minimum temperature due to inhibited radiational cooling, during the important 'hardening-off' period at the end of the growing season.

The consistently strongest correlations for all of the significant year $t$ months are from the $\mathrm{BCH}$ site. The only significant $t-1$ correlations for the HIGH chronologies are positive with April mean temperature (LJH, BCH, LMH), May mean temperature $(\mathrm{LJH})$, and April maximum temperature $(\mathrm{BCH})$. There are no significant correlations with precipitation for any months in year $t-1$ for any of the HIGH chronologies.

The three LOW chronologies exhibit a direct response to warm season temperature in year $t$ which is considerably weaker than that of the three HIGH sites. They 

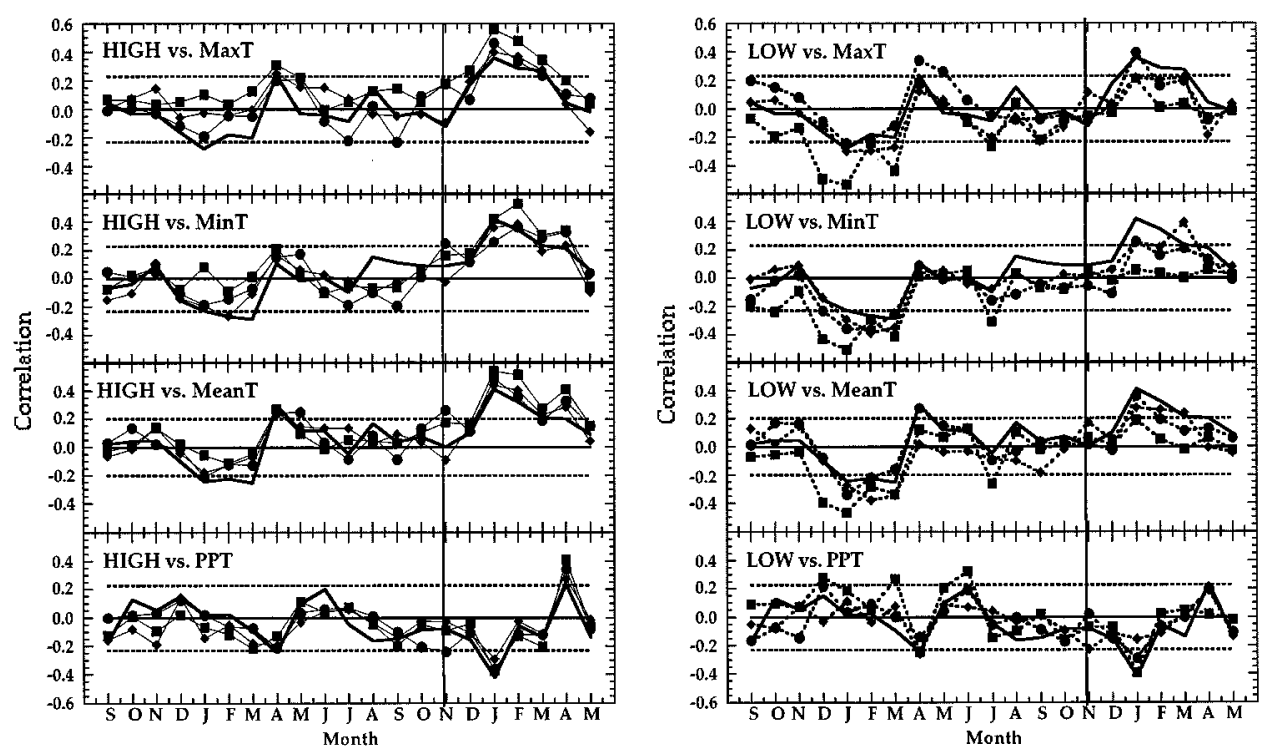

Figure 7. Climate response plots for the HIGH and LOW chronologies. The left hand plots show the correlation functions for the three HIGH chronologies plotted as solid black lines $(\mathrm{LJH}=$ circle; $\mathrm{BCH}=$ square; $\mathrm{LMH}=$ diamond) with, from top to bottom, maximum temperature, minimum temperature, mean temperature, and precipitation. The plots on the right illustrate the same correlation functions for the three LOW chronologies represented by the dashed lines $(\mathrm{LVH}=$ circle; $\mathrm{HAR}=$ square; $\mathrm{SRT}=$ diamond). The 700 metre LML chronology, shown as the heavy, solid black line, is included in all plots for comparison purposes. The horizontal dashed lines represent the 95\% confidence limits, while the vertical line marks the beginning of the current growth season in November, extending to May on the extreme right. A 21 month dendroclimatic window is shown back to September preceeding the previous growth season on the extreme left.

also reveal a significant $(p<0.05)$, inverse response to temperature in the previous warm season, which is strongest in the HAR chronology. The strongest temperature response window for the LOW sites is from December-March of year $t-1$, with the highest correlations associated with minimum temperature for January, February and March. This same response is weakly apparent in the HIGH sites but is not statistically significant in any of them. The response of the 700-metre LML site falls almost directly between the two groupings, thereby supporting an expected increase in the fidelity of the year $t$ response to temperature with elevation, based on the principle of limiting factors (Fritts, 1976). Precipitation exhibits weaker correlations and greater variation between sites with the LOW rather than with the HIGH chronologies. HAR exhibits a significant, direct response with December, March, and June of year $t-1$, and negative with April $(t-1)$, and January of year $t$. The only other significant correlations with precipitation are for $\mathrm{LVH}$; inverse with January of year $t$.

The strong response to temperature in year $t-1$ for the LOW sites is not presently well understood. It is plausible that warm growing season conditions result in optimum growth rates which in turn deplete stores of carbohydrate and 
nutrients for the following season, given the nutrient-poor conditions of the soils and the extremely slow growth rates for Huon pine (Buckley, 1997). As noted earlier, the temperature at subalpine sites seldom exceeds optimum levels for photosynthesis, and combined with cold winter conditions which initiate dormancy, such carbohydrate and nutrient depletion would be less likely to occur. The weak correlations with precipitation for all LOW sites argue against a drought-stress response to high temperature and dry conditions as the source of the year $t-1$ temperature response, though further research is required to clarify this.

\section{Rotated PCA}

A rotated Principal Component Analysis (PCA) (Richman, 1986) is performed on the seven prewhitened Residual chronologies. The results are plotted in Figure 8, and listed in Table VI. The period of analysis is from 1560-1982, which accounts for the maximum period of overlap between all seven chronologies. Only the first two PCs are significant at the 0.05 level, a result based on the rigorous Monte Carlo test which validates the rotation of the first two eigenvectors (Preisendorfer et al., 1981). Both before and after varimax rotation the grouping of the chronologies into two distinct clusters by elevation is evident. The first two eigenvectors, with eigenvalues greater than 1.0, explain $72.3 \%$ of the total variance among the series. The first eigenvector represents the high-elevation sites, while the second eigenvector is related to those sites below 700 metres. The 700-metre LML site again appears as a transitional site between the two groupings, with about equal variance for both eigenvectors. This reinforces the notion of a physiological threshold located near the 700 metre contour, where Huon pine's climatic requirements begin to drop below optimum levels for photosynthesis for at least the period of calibration over the past ca. 100 years. Since the rotated PCA includes data from all seven chronologies well before the calibration period (i.e., from 1560-1888) this same elevation-dependent climate response might be inferred to have remained stable throughout this period.

\section{Vertical Climate Structure in Western Tasmania}

The results presented above suggest that an important environmental zone exists near the 700 metre contour in western Tasmania, where a physiological threshold is reached with regard to Huon pine's climatic requirements, as temperature drops below optimum levels and becomes directly-limiting to growth. As noted earlier, Mt. Read's sea-level-equivalent mean warm-season temperature is around $14^{\circ} \mathrm{C}$. Using adiabatic lapse rates for dry and saturated air of $1.0^{\circ} \mathrm{C} / 100 \mathrm{~m}$ and $0.56{ }^{\circ} \mathrm{C} / 100 \mathrm{~m}$, respectively (for air at ca. $10^{\circ} \mathrm{C}$ and $1000 \mathrm{mb}$ pressure), the mean warm-season temperature for elevations of 700 metres over the same period can be 


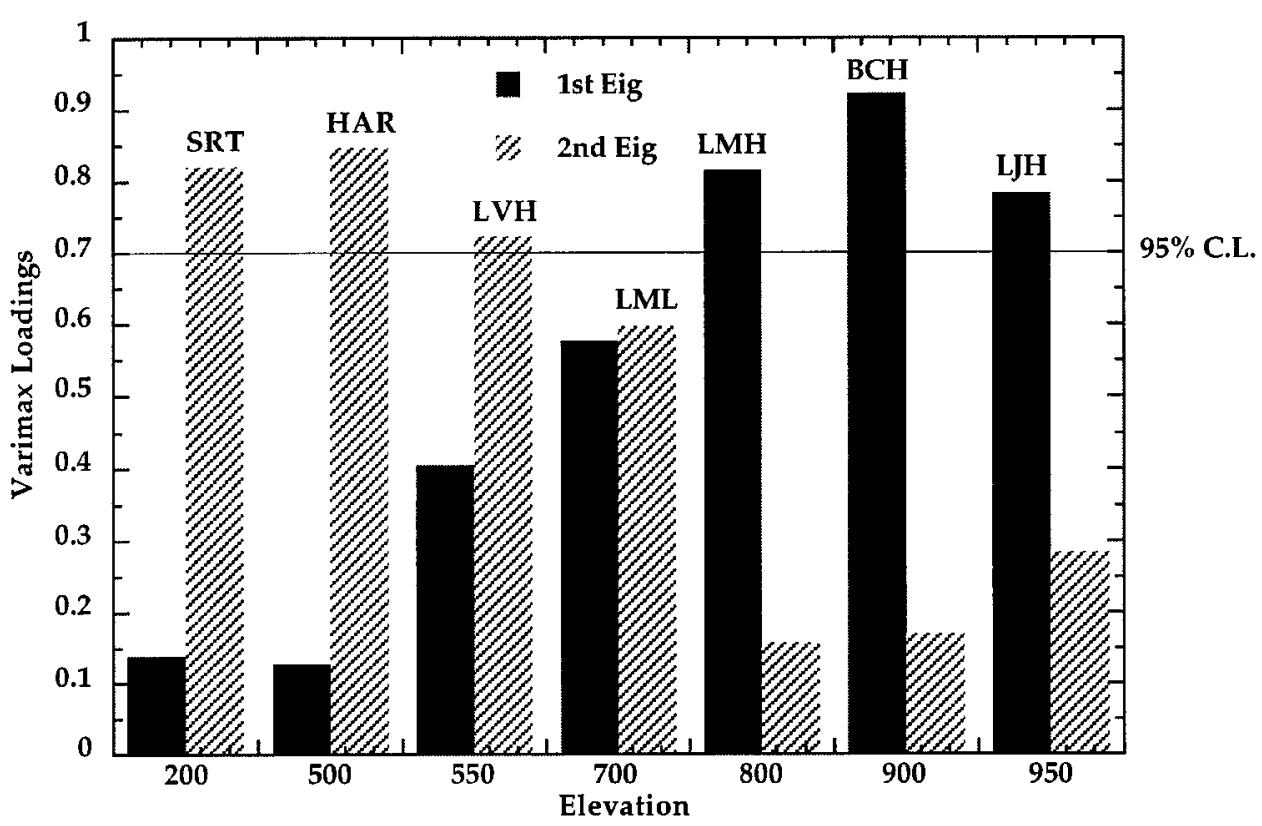

Figure 8. Varimax loadings for the first and second eigenvectors from the seven Huon pine chronologies.

Table VI

Results from a rotated PCA, with an analysis period from 1560 to 1982. This method of analysis does not presume any relationships between the chronologies. The rotated varimax loadings clearly illustrate the separation of the chronologies by elevation into two groups centred on 700 metres

\begin{tabular}{|c|c|c|c|c|c|c|c|}
\hline No. & Eigenvalue & $\%$ Variance & Cumulative & $\%$ & & 95\% Limit & \\
\hline 1 & $3.900^{\mathrm{a}}$ & 55.713 & 55.713 & & & 1.251 & \\
\hline 2 & $1.162^{\mathrm{a}}$ & 16.604 & 72.317 & & & 1.151 & \\
\hline 3 & 0.577 & 8.240 & 80.558 & & & 1.088 & \\
\hline 4 & 0.486 & 6.945 & 87.503 & & & 1.032 & \\
\hline 5 & 0.415 & 5.922 & 93.424 & & & 0.983 & \\
\hline 6 & 0.291 & 4.163 & 97.587 & & & 0.929 & \\
\hline 7 & 0.169 & 2.413 & 100.000 & & & 0.876 & \\
\hline Eigen & $\mathrm{LJH}$ & $\mathrm{BCH}$ & $\mathrm{LMH}$ & LML & LVH & HAR & SRT \\
\hline \multicolumn{8}{|c|}{ Unrotated eigenvector loadings } \\
\hline 1 & 0.3901 & 0.4034 & 0.3590 & 0.4179 & 0.3977 & 0.3366 & 0.3317 \\
\hline 2 & -0.2950 & -0.4598 & -0.4019 & 0.0518 & 0.2421 & 0.5021 & 0.4760 \\
\hline \multicolumn{8}{|c|}{ Rotated varimax loadings } \\
\hline 1 & $0.7838^{\mathrm{b}}$ & $0.9227^{\mathrm{b}}$ & $0.8159^{\mathrm{b}}$ & 0.5726 & 0.4049 & 0.1270 & 0.1388 \\
\hline 2 & 0.2837 & 0.1699 & 0.1571 & 0.5970 & $0.7219^{\mathrm{b}}$ & $0.8479^{\mathrm{b}}$ & $0.8205^{\mathrm{b}}$ \\
\hline
\end{tabular}

${ }^{a}$ First two eigenvectors with eigenvalues $>1$ are rotated.

${ }^{\mathrm{b}}$ Chronologies that load similarly and significant at 0.05 level. 


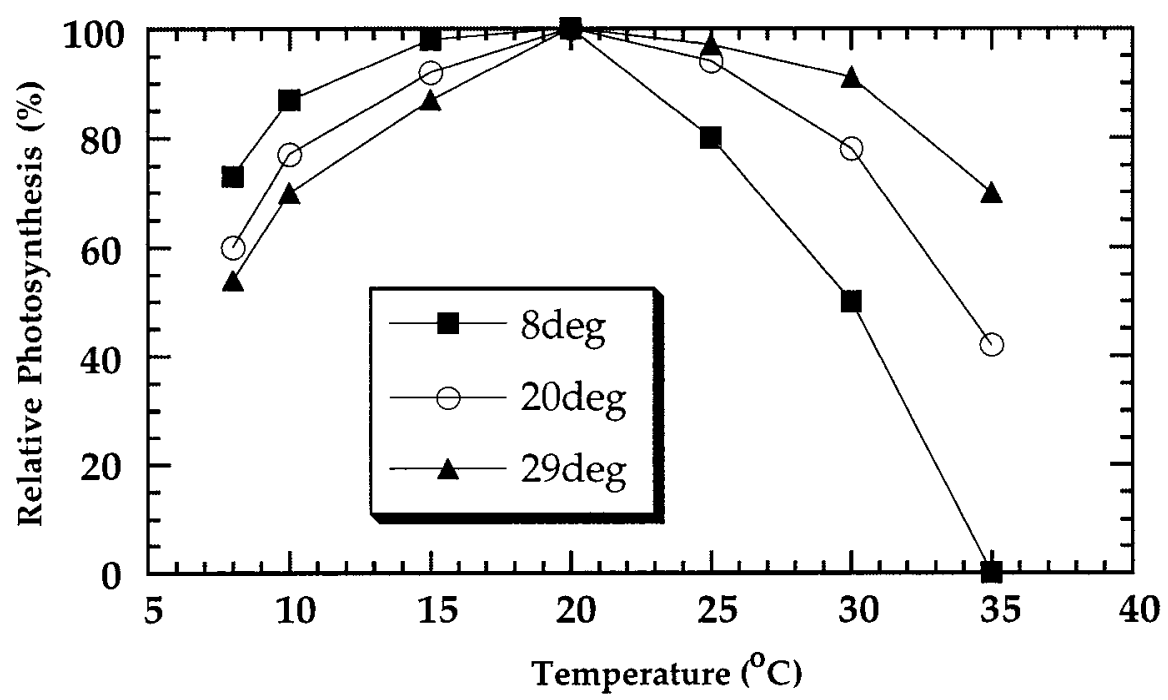

Figure 9. The response of net photosynthesis in Huon pine to instantaneous temperatures in foliage acclimated to three temperatures; $8^{\circ}, 20^{\circ}$, and $29^{\circ} \mathrm{C}$, respectively. The rates of net photosynthesis are expressed as a percentage of the maximum rate of photosynthesis recorded for that acclimation temperature. Each value represents the mean of five replicates from samples taken from the Picton River in southern Tasmania at an elevation of 80 metres. The optimum temperature for photosynthesis is $20^{\circ} \mathrm{C}$ for all acclimation temperatures. The lowest acclimation temperature produced the highest rates of net photosynthesis at cooler temperatures, and the lowest rates when instantaneous temperature exceeds $20^{\circ} \mathrm{C}$. Conversely, a higher acclimation temperature resulted in reduced net photosynthesis at lower temperature, and enhanced rates at higher temperatures. (Adapted from Read and Busby, 1990.)

calculated to range from about $7^{\circ}$ to $10^{\circ} \mathrm{C}$, respectively. For elevations of 1,000 metres the range is from $5^{\circ}$ to around $8.5^{\circ} \mathrm{C}$. Read and Busby (1990) demonstrate that the optimum temperature for net photosynthesis in Huon pine is around $20^{\circ} \mathrm{C}$, with a reduction in net photosynthesis below $10^{\circ}$ and, rather sharply, above $25^{\circ}$, particularly for specimens acclimated at low temperature (see Figure 9). The interannual variability of temperature might therefore be expected to account for a large percentage of the variability of annual growth, as is the case for LJH where nearly $37 \%$ of the variance in annual incremental growth can be explained by the mean warm-season temperature from the Cook Series (Cook et al., 1992).

Based on the adiabatic lapse rates alone, it therefore appears that the 700 metre contour might correspond to a critical environmental zone with regard to photosynthetic activity in Huon pine, as mean warm-season temperature drops to near or below $10{ }^{\circ} \mathrm{C}$. Above this zone, temperature during the season of growth becomes increasingly more directly-limiting to growth through the inhibition of net photosynthesis during prolonged periods of low temperature and increased cloudiness. Extended periods of temperature above $25^{\circ} \mathrm{C}$ at subalpine locations would be very rare. For example, daily temperature recorded from within the 950-metre LJH site for the Austral summer of 1994 (one of Tasmania's warmest summers on record) 
Table VII

Statistics of Mt. Read daily temperature records from Dec. 20, 1994 to Dec. 12, 1995. 'Sum 1' is from Dec 20, 1994 to March 31, 1995, 'Win 1' is from May 1 to August 31, 1995, 'Sum 2 ' is from Nov. 1 to Dec. 12, 1995. 'Max' columns show the statistics for the daily maximum temperatures, while 'Min' columns refer to daily minimum temperature. (Data supplied courtesy of David Pepper, University of Sydney.)

\begin{tabular}{lrrrrrr}
\hline & Max Sum 1 & Max Win 1 & Max Sum 2 & Min Sum 1 & Min Win 1 & Min Sum 2 \\
\hline Min. & 3.30 & -0.70 & 3.20 & -2.90 & -4.50 & -1.10 \\
Max. & 28.90 & 10.00 & 19.40 & 14.30 & 8.20 & 6.90 \\
N & 102.00 & 123.00 & 42.00 & 102.00 & 123.00 & 42.00 \\
Mean & 14.13 & 3.98 & 10.09 & 5.89 & 0.36 & 2.13 \\
Median & 14.15 & 3.80 & 10.25 & 5.80 & 0.00 & 2.30 \\
Std. Dev. & 6.08 & 2.53 & 3.48 & 3.76 & 2.19 & 1.93 \\
Variance. & 36.95 & 6.40 & 12.18 & 14.17 & 4.80 & 3.74 \\
Std. Error & 0.60 & 0.23 & 0.54 & 0.37 & 0.20 & 0.30 \\
\hline
\end{tabular}

reveals a mean maximum of $14.1^{\circ}$, an absolute maximum of $28.9^{\circ}$, and a minimum maximum of $3.3^{\circ} \mathrm{C}$ (see Table VII). Minimum temperature for that same summer had a mean of $5.9^{\circ}$, a maximum of $14.3^{\circ}$, and a minimum of $-2.9^{\circ} \mathrm{C}$ (data courtesy of D. Pepper, University of Sydney). At lower elevations it is possible that prolonged temperatures above $25^{\circ} \mathrm{C}$ may inhibit photosynthesis in some years, and this may partially explain the strong, inverse response to temperature in the prior year for the LOW chronologies, as discussed above.

Along with temperature, the effects of cloudiness and moisture availability combine to further influence net photosynthesis in Huon pine. Moisture availability alone is not problematic for subalpine stands of Huon pine in western Tasmania, where the median annual rainfall totals in the mountainous areas exceed 3,000 $\mathrm{mm}$. It is therefore likely that the role of moisture availabilty is a minor one, except for as it relates to temperature and light-availability. Drought is not entirely unknown in the rainforest areas of western Tasmania, and it is possible for trees to go into moisture deficit under conditions of high temperature and low water availability. However, these conditions would not be expected to persist for more than a matter of days at subalpine sites. For example, the warm summer of 1994 noted above, experienced only 16 days when the maximum temperature on Mt. Read exceeded $20^{\circ} \mathrm{C}$, and only 6 of those days exceeded $25^{\circ}$. Mean daily temperature throughout the summer never exceeded $20^{\circ} \mathrm{C}$.

Perhaps more important above 700 metres is the role of cloudiness and its effects on temperature, light availability, and therefore photosynthesis. For example, the annual mean-maximum temperature for stations such as Strathgordon (elevation $320 \mathrm{~m}$ ) and Savage River $(365 \mathrm{~m})$ is $14.0^{\circ}$ and $14.2^{\circ} \mathrm{C}$, respectively, and the mean 3:00 PM relative humidity is around 70\% (Bureau of Meteorology, 1993). This implies a dewpoint of about $7{ }^{\circ} \mathrm{C}$ which gives an average cloud base of 
approximately 800 metres above terrain at the warmest time of the day, translating into a mean cloud base of approximately $1,100 \mathrm{~m}$ AMSL. For the bulk of the time, however, the cloud base is less than $500 \mathrm{~m}$ above the terrain and probably $500 \mathrm{~m}$ AMSL or less early in the morning (M. Pook, pers. comm.). The net effect is a dynamic cycle of light, temperature and moisture below 1,000 metres, with an alpine zone regularly in cloud. This is interrupted during times of slackened zonal circulation and easterly conditions, such as during atmospheric blocking events (M. Pook, pers. comm.). Trees on windward slopes at higher elevations likely experience even lower temperature and less light, as they would spend much of their time in dense, orographically-generated cloud, resulting in reduced photosynthesis and suppressed growth.

Vertical zonation of climate in western Tasmania is proposed by Kirkpatrick and Brown (1987) to explain the existence of a sharp vegetation boundary between sedgeland and alpine flora above 700 metres in southwestern Tasmania, from four different mountains ranging nearly $60 \mathrm{kms}$ in a northwest-southeast transect. The boundary can not be attributed to species interactions, and persists on all four mountains despite an apparent climatic, geologic, edaphic and topographic continuity of the environment. The authors hypothesise the most likely cause of this boundary to be climatic, in the form of a persistent cloud ceiling with a mean position somewhere above 700 metres, though they lacked the data to properly test this hypothesis. Kirkpatrick et al. (in press) later confirm this model, following two years of climate monitoring on Mt. Sprent in southwestern Tasmania. They demonstrate a frequent subsidence-inversion layer between 850 and 930 metres, along with a sharp change in vegetation which is coincident with a rapid decrease in temperature and increase in relative humidity (see Figure 10). Air and soil temperature decrease most steeply in this zone, while humidity is at its highest levels. Both above and below this layer are zones of more gradual change, between 930 and 1,050 metres, and 510 and 820 metres, respectively.

The regional-scale inversion is related to atmospheric subsidence associated with the passage of high pressure systems over Tasmania. Kirkpatrick et al. (in press) note that the height of the inversion base in the free air can be observed by examining the daily radiosonde soundings from Hobart Airport, which indicates the median height to be around 1,138 m AMSL; higher than that noted for Mt. Sprent due to the effect of radiative cooling of the earth's surface which lowers the height of the inversion in the west coast mountains. A gradual west-to-east increase in the inversion height is also expected as air flows over successive orographic obstacles.

This vertical climate zonation model adequately accounts for the different mean climatic regimes for lowland and subalpine sites in western Tasmania, and is consistent with the results from the climate response modelling and the rotated PCA presented in this paper. Periods of common variance between the HIGH and LOW chronologies may be explained by extended periods of uniform conditions of cloudiness, or persistent periods of clear skies and increased solar radiation. A 


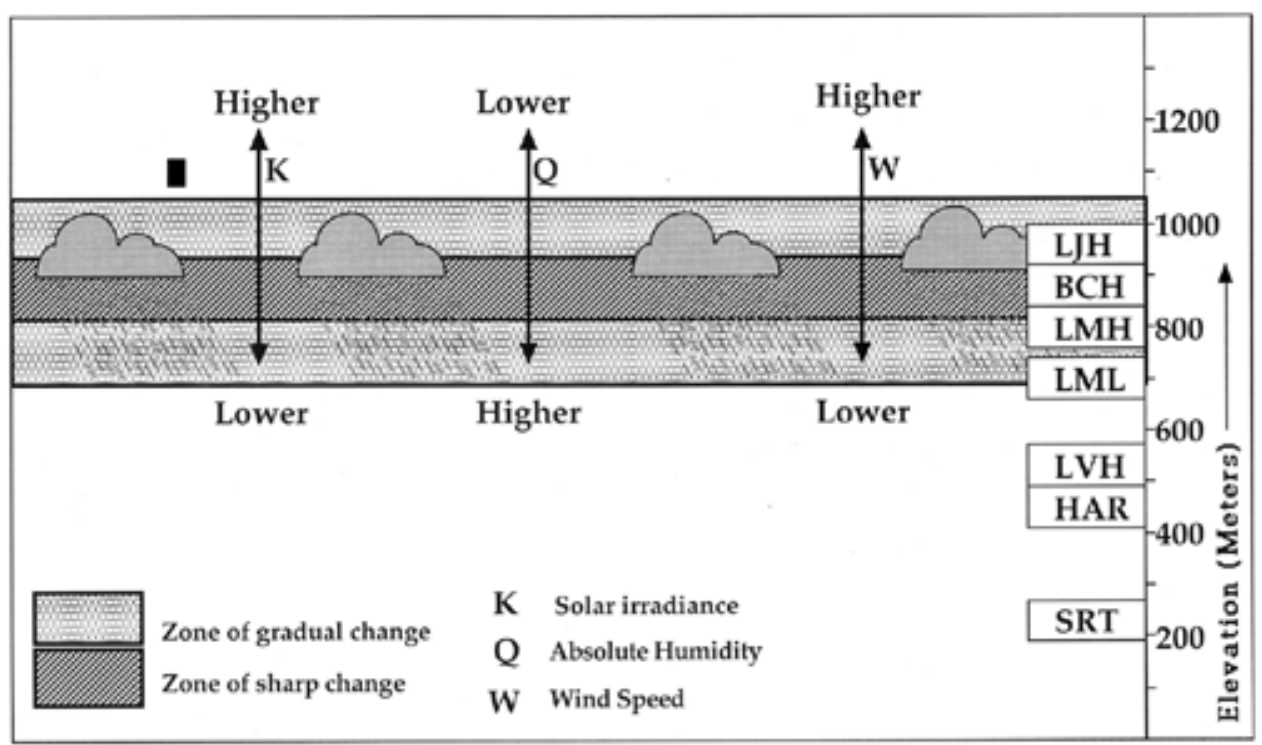

Figure 10. Schematic illustration of the vertical climate structure over Tasmania's west coast mountains. (Adapted from Kirkpatrick et al., in press.)

record of past changes in this vertical structure can likely be modelled through the careful use of such elevational chronology-networks as that presented here.

\section{Conclusions}

The subalpine Huon pine chronologies presented in this paper exhibit a more robust and easily-interpreted response to climate than do sites from below 700 metres in elevation. While the very long time periods afforded by lower-elevation sites allow for important palaeo-environmental information from key periods of the Holocene (e.g., the Younger Dryas, and the Hypsithermal), and are crucial for the inter-hemispheric comparison of ${ }^{14} \mathrm{C}$ production (Barbetti et al., 1995), it is the subalpine chronologies that yield the most reliable information about past climate variability in Tasmania, using traditional dendroclimatic techniques. Changes in the vertical structure of Tasmania's west coast climate, related to synoptic climate changes, may be best analysed through the use of elevational transects like that presented in this paper.

In addition to its demonstrated climate-sensitivity, Tasmanian Huon pine has proven to be an important species for palaeo-environmental study due to a combination of its longevity and its preservation qualities. Individuals regularly attain more than 1,000 years, and occasionally more than 2,000 years in age (Buckley, 1997). Preservation of Huon pine log sections is due to the extractive methyl eugenol which serves to retard decay from microbial activity (Millington et al., 1979), and 
logs dating throughout the Holocene have been excavated from the Stanley River, with some logs dating more than 38,000 radiocarbon years before present (Barbetti et al., 1992; 1995; Barbetti, pers. comm.). Preservation of stemwood in the harsher, subalpine environment on Mt. Read appears to be less effective, possibly due to mechanical erosion through ice-abrasion, combined with less-rapid rates of deposition and burial of downed logs (Buckley, 1997). The oldest material so far recovered from Mt. Read dates back nearly 5,000 years, in spite of pollen evidence that the LJH stand has existed for at least the past 10,000 years (Anker et al., 1997). It is not yet clear if logs older than 5,000 years will be recoverable from Mt. Read and other subalpine locations, or if the conditions of exposure at such sites inhibit preservation for longer periods of time.

Future efforts should be focussed on the discovery and sampling of additional subalpine sites, and on the search for subfossil wood of ever-increasing age. More research into the spatial and temporal characteristics of the vertical zonation of climate, as discussed in this paper, should be explored along with more mechanistically-based physiological research on the response of Huon pine to environmental conditions such as climate. A more thorough understanding of the biological and physiological factors contributing to the strong, inverse prior-year temperature response for low-elevation sites would enable a better utilisation of the very long records obtained from these sites.

\section{Acknowledgements}

We would like to thank several people for their assistance with the development of the chronologies presented here: Zhao Yu and Bruce Thompson from the University of Sydney; Rob Wilson, Adrian Lewis, and Jason Whitehead from the University of Tasmania; and Pete Kelly and Ken Peters from Lamont-Doherty Earth Observatory. Special thanks go to members of our field research teams over the past few years, in particular Garn Cooper, Annie Wong, Kathy Allen, Rob Argent, Gillian Taylor, Trevor Bird, Roger Francey, Daryl Mummery, Paul Krusic and Dave Stahle. Important meteorological data from Mt. Read were generously made available by David Pepper, University of Sydney. We thank Dr. Mike Pook, Dr. Tim Gibson, and Dr. Andrew Ruddel from the Antarctic CRC, University of Tasmania, and Simon Torok from the University of Melbourne, for helpful comments on the manuscript. We also express our gratitude to Pasminco, Forestry Tasmania and the Department of Parks, Wildlife \& Heritage, Tasmania for their cooperation and assistance throughout this project. Various aspects of this research were funded by several granting agencies, including the National Greenhouse Advisory Committee of the Commonwealth of Australia; the National Science Foundation of the USA; and the Australian Research Council. Lamont-Doherty contribution no. 5669. 


\section{References}

Anker, S. A., Colhoun, E. A., Barton, C. E., Peterson, M., and Barbetti, M.: 1997, Holocene Vegetation, Palaeoclimatic and Palaeomagnetic History from Lake Johnston, Tasmania, in preparation.

Barbetti, M., Bird, T., Dolezal, G., Taylor, G., Francey, R. J., Cook, E. R., and Peterson, M. J.: 1992, 'Radiocarbon Variations from Tasmanian Conifers: First Results from Late Pleistocene and Holocene Logs', Radiocarbon 34 (3), 806-817.

Barbetti, M., Bird, T., Dolezal, G., Taylor, G., Francey, R., Cook, E., and Peterson, M.: 1995, 'Radiocarbon Variations from Tasmanian Conifers: Results from Three Early Holocene Logs', in Cook, G. T., Harkness, D. D., Miller, B. F., and Scott, E. M. (eds.), Radiocarbon, The 15th International ${ }^{14} \mathrm{C}$ Conference, 37, Tucson, Arizona, pp. 361-369.

Buckley, B. M.: 1997, Climate Variability in Tasmania Based on Dendroclimatic Studies of Lagarostrobos franklinii, Ph.D. Thesis, IASOS, University of Tasmania, Hobart, Australia.

Buckley, B. M., Peterson, M. J., and Cook, E. R.: 1993, 'Changes in the Climatic Response of Huon Pine with Elevation in Western Tasmania, Australia', in Hill, R. S. (ed.), Abstracts, Southern Temperate Ecosystems: Origin and Diversification, The Australian Systematic Botany Society and the Ecological Society of Australia, Hobart, Tasmania, p. 28.

Bureau of Meteorology: 1993, Climate of Tasmania, Commonwealth of Australia Report, March 1993, p. 30.

Cook, E. R.: 1985, A Time Series Analysis Approach to Tree-Ring Standardization, Ph.D. Dissertation, University of Arizona, Tucson, p. 171.

Cook, E. R.: 1987, 'The Decomposition of Tree-Ring Series for Environmental Studies', Tree-Ring Bull. 47, 37-59.

Cook, E. R. and Kairiukstis, L. A. (eds.): 1990, Methods of Dendrochronology: Applications in the Environmental Sciences (1 edn.), Kluwer Academic Publishers, Dordrecht, p. 394.

Cook, E. R., Bird, T., Peterson, M., Barbetti, M., Buckley, B., D’Arrigo, R., Francey, R., and Tans, P.: 1991, 'Climatic Change in Tasmania Inferred from a 1089-Year Tree-Ring Chronology of Huon Pine', Science 253, 1266-1268.

Cook, E. R., Bird, T., Peterson, M., Barbetti, M., Buckley, B., D’Arrigo, R., and Francey, R.: 1992, 'Climatic Change over the Last Millennium in Tasmania Reconstructed from Tree Rings', The Holocene 2, 205-217.

Cook, E. R., Buckley, B. M., and D'Arrigo, R. D.: 1995, 'Decadal-Scale Oscillatory Modes in a Millennia-Long Temperature Reconstruction from Tasmania', in Martinson, D. G., Bryan, K., Ghil, M., Hall, M. M., Karl, T. R., Sarachik, E. S., Sorooshian, S., and Talley, L. D. (eds.), Natural Climate Variability on Decade-to-Century Time Scales, National Academy Press, Washington, D.C., pp. 523-532.

Cook, E. R., Buckley, B. M., and D'Arrigo, R. D.: 1996a, 'Inter-Decadal Climate Oscillations in the Tasmanian Sector of the Southern Hemisphere: Evidence from Tree Rings over the Past Three Millennia', in Jones, P. D. and Bradley, R. S. (eds.), Climatic Variations and Forcing Mechanisms of the Last 2000 Years, Springer-Verlag, Berlin and Heidelberg, pp. 141-160.

Cook, E. R., Francey, R. J., Buckley, B. M., and D'Arrigo, R. D.: 1996b, 'Recent Increases in Tasmanian Huon Pine Ring Widths from a Subalpine Stand: Natural Climate Variability, $\mathrm{CO}_{2}$ Fertilization, or Greenhouse Warming?', Papers and Proceedings of the Royal Society of Tasmania 130 (2), 65-72.

Francey, R. J., Barbetti, M., Bird, T., Beardsmore, D., Coupland, W., Dolezal, J. E., Farquhar, G. D., Flynn, R. G., Fraser, P. J., Gifford, R. M., Goodman, H. S., Kunda, B., McPhail, S., Nanson, G., Pearman, G. I., Richards, N. G., Sharkey, T. D., Temple, R. B., and Weir, B.: 1984, Isotopes in Tree Rings, Division of Atmospheric Research Technical Paper No. 4, CSIRO, Australia.

Fritts, H. C.: 1976, Tree Rings and Climate, Academic Press, London, p. 567.

Gentilli, J.: 1972, Australian Climate Patterns, Nelson, Melbourne, Australia.

Hickey, J. E. and Felton, K. C.: 1988, 'Subalpine Huon Pine near Frenchmans Cap', The Tasmanian Naturalist 93, 1-4.

Hughes, M. K., Kelly, P. M., Pilcher, J. R., and LaMarche Jr., V. C. (eds.): 1982, Climate from Tree Rings, Cambridge University Press, Cambridge, p. 223. 
Jarman, S. J., Brown, M. J., and Kantvilas, G.: 1984, Rainforest in Tasmania, Department of Parks, Wildlife and Heritage Report, Hobart, Tasmania.

Kirkpatrick, J. B. and Brown, M. J.: 1987, 'The Nature of the Transition from Sedgeland to Alpine Vegetation in South-West Tasmania. I. Altitudinal Vegetation Change on Four Mountains', $J$. Biogeogr. 14, 539-549.

Kirkpatrick, J. B., Nunez, M., Bridle, K., and Chladil, M. A.: 1997, 'Explaining a Sharp Transition from Sedgeland to Alpine Vegetation on Mount Sprent, South-West Tasmania', J. Vegetation Science, in press.

Langford, J.: 1965, 'Weather and Climate', in: Davies, J. L. (ed.), Atlas of Tasmania, Department of Lands and Surveys, Hobart, Australia, pp. 2-11.

Macphail, M. K.: 1979, 'Vegetation and Climates in Southern Tasmania since the Last Glaciation', Quater. Res. 11, 306-341.

Millington, R. J., Jones, R., Brown, D., and Vernon, B.: 1979, Huon Pine - Endangered? (Environmental Studies Occassional Paper No. 9), University of Tasmania, p. 120.

Nanson, G. C., Barbetti, M., and Taylor, G.: 1995, 'River Stabilisation Due to Changing Climate and Vegetation during the Late Quaternary in Western Tasmania, Australia', Geomorphology 13, $145-158$.

Peterson, M. J.: 1990, Distribution and Conservation of Huon Pine, Forestry Commission Tasmania Report, Hobart, Australia, p. 45.

Preisendorfer, R. W., Zwiers, F. W., and Barnett T. P.: 1981, Foundations of Principal Components Selection Rules, SIO Reference Series, 81-4, Scripps Institution of Oceanography, La Jolla, U.S.A.

Read, J. and Busby, J. R.: 1990, 'Comparative Responses to Temperature of the Major Canopy Species of Tasmanian Cool Temperate Rainforest and Their Ecological Significance. II. Net Photosynthesis and Climate Analysis', Aust. J. Botany 38, 185-205.

Richman, M. B.: 1986, 'Rotation of Principal Components', J. Climatol. 6, 293-335.

Stokes, M. A. and Smiley, T. L.: 1968, An Introduction to Tree-Ring Dating, University of Chicago Press, Chicago, p. 73.

Torok, S. J.: 1996, The Development of a High Quality Historical Data Base for Australia, Ph.D. Thesis, School of Earth Sciences, Faculty of Science, The University of Melbourne, Australia. 